\title{
Soil nematode responses to heavy metal stress
}

\author{
W. D. ZHANG ${ }^{1,2}$, X. F. WANG ${ }^{1,2}$, Q. LI $^{1,3}$, Y. JIANG ${ }^{1}$, W. J. LIANG ${ }^{1, *}$
}

\begin{abstract}
${ }^{1}$ Key Laboratory of Terrestrial Ecological Process, Institute of Applied Ecology, Chinese Academy of Sciences, Shenyang 110016, China, E-mail: liangwj@iae.ac.cn; ${ }^{2}$ College of Life Sciences, Liaoning Normal University, Dalian 116029, China; ${ }^{3}$ Graduate University, Chinese Academy of Sciences, Beijing 100049, China
\end{abstract}

\begin{abstract}
Summary
The effect of $\mathrm{Cu}$ and $\mathrm{Zn}$ on soil nematode communities at the depth of $0-20 \mathrm{~cm}$ was investigated along a pollution gradient with increasing distance from a copper smelter in Northeast China. The results showed that the abundance of total nematodes significantly increased with increasing distance from the smelter, and nematode taxon richness also exhibited an increasing trend. Twenty genera were observed in our study, and Paratylenchus was the dominant genus at all the sampling sites. The numbers of total nematodes, bacterivores, plant parasites, omnivores-predators and the values of NCR (Nematode Channel Ratio) negatively correlated with total $\mathrm{Cu}(\mathrm{P}<0.01)$, total and available $\mathrm{Zn}(\mathrm{P}<0.01)$. The values of SI (Structure Index) negatively correlated with total $\mathrm{Cu}(\mathrm{P}<0.05)$. Among the nematode ecological indices examined, NCR and SI were found to be sensitive indicators for assessing the effect of heavy metals on soil nematode communities in this study.
\end{abstract}

Key words: soil nematode; community structure; ecological indices; copper smelter; heavy metals

\section{Introduction}

Emission of toxic substances from metal smelters not only causes air pollution but also soil contamination (ToborKapłon et al., 2006). These substances, including $\mathrm{Cu}, \mathrm{Zn}$, $\mathrm{Pb}$ and $\mathrm{Cd}$, are usually dispersed in relatively higher concentrations in the vicinity of a smelter, with a gradual depletion as distance from the source increases (Shukurov et al., 2005). Heavy metal contamination can change the functioning of soil ecosystems by disturbing the activities of soil fauna (Cortet et al., 1999). Because nematodes occupy key positions as primary and intermediate consumers in soil food webs, evaluation and interpretation of the abundance and function of their faunal assemblages or community structure could offer an in situ assessment of stress factors (Bongers \& Ferris, 1999). Changes in soil nematode community structure have been used very successfully in assessing the ecotoxicological effects of different soil disturbances including heavy metal pollution and fertilization (Neher, 2001; Li et al., 2006; Liang et al., 2006).

In recent years, there have been many reports of the impact of heavy metals on soil nematode assemblages (Yeates et al., 2003). Georgieva et al. (2002) found that $\mathrm{Cu}$ and $\mathrm{Zn}$ had a negative effect on various parameters of a nematode assemblage on a sandy loam in England. Nagy et al. (2004) reported that increased Se and Cr concentrations resulted in a significant decrease in nematode density, generic richness and maturity index (MI2-5) on a calcareous chernozem soil in Hungary. Shukurov et al. (2005) studied the effect of heavy metals on soil nematodes along the emission gradient of the Almalyk Industrial Complex, Uzbekistan, and showed a significant correlation between the number of total nematodes and the distance from the pollution source. Similar results were also observed by $\mathrm{Li}$ et al. (2006) in the study of the effect of heavy metals on soil nematode communities in the vicinity of a metallurgical factory in Northeast China. However, little information is available concerning soil nematode responses to heavy metals near a smelter in Northeast China (Li et al., 2006). The objectives of this study were to investigate soil nematode responses to heavy metals along a pollution gradient with increasing distance from a copper smelter in Northeast China, and to evaluate the relationship between nematode ecological indices and concentrations of heavy metals in soil.

\section{Materials and Methods}

This study was conducted at corn fields along a pollution gradient from the Hongtoushan Copper Smelter $\left(41^{\circ} 59^{\prime} \mathrm{N}\right.$,

\footnotetext{
${ }^{*}$ Corresponding author
} 
$\left.104^{\circ} 31^{\prime} \mathrm{E}\right)$, the largest enterprise in the Mountain Area of East Liaoning, Northeast China. The smelter produces crude copper and has a capacity for processing approximately 11500 tons per year. Due to a lack of air-treatment facilities for copper smelting, the smelter is also a major source of air pollution. This study area is located in the continental temperate monsoon zone, with a dry-cold winter and a warm-wet summer. The annual mean temperature is $5.1^{\circ} \mathrm{C}$, annual precipitation averages $863 \mathrm{~mm}$. The soil at the study site is a Cambisol (FAO classification) and the previous crop is corn (Zea mays L.).

Soil samples were taken from corn fields along a pollution gradient, in a downwind direction from the smelter emission sources. The soil samples were collected from $0-20$ cm layer at 50 (site A), 150 (site B), 500 (site C) and 1000 (site D) $\mathrm{m}$ along the pollution gradient in November 2006. At each sampling site, four plots $\left(10 \times 10 \mathrm{~m}^{2}\right.$ for each plot $)$ were randomly selected; four replications were collected in each plot by coring techniques $(5 \mathrm{~cm}$ diameter $\times 20 \mathrm{~cm}$ depth). Each replication was composed of 5 soil cores. Soil samples were placed in individual plastic bags and transported to the laboratory for chemical and nematode analysis.

Before analysis, soil samples were air-dried and ground to pass through a $2 \mathrm{~mm}$ sieve for determination of available metals. Subsamples were then ground and passed through a $149 \mu \mathrm{m}$ sieve for determination of total metals. For total metals, soil samples were digested with $\mathrm{HNO} 3-\mathrm{HClO} 3$ $(3: 1, v / v)$ and determined using AAS (WFX120A) with a detecting limit of $0.01 \mathrm{mg} / \mathrm{L}$ for $\mathrm{Cu}$ and $\mathrm{Zn}$. The concentrations of available heavy metals in soil samples were determined after extraction with $0.1 \mathrm{~mol} / \mathrm{L} \mathrm{HCl}$ (solid: liquid = 1:5) (Li et al., 2006; Liang et al., 2006). Soil physicochemical properties at different sites were showed in Table 1.

Nematodes were extracted from $100 \mathrm{~g}$ (fresh weight) of soil from each sample using sugar flotation and centrifugation (Hua et al., 2006; Liang et al., 2006; Liu et al., 2006), the nematode abundance was expressed per $100 \mathrm{~g}$ dry weight soil (Liang et al., 2007). All extracted nematodes in each sample were counted and identified to genus level using an inverted compound microscope. The classification of trophic groups was assigned to: (1) bacterivores; (2) fungivores; (3) plant-parasites; and (4) omnivores-predators, based on known feeding habitats or stoma and esophageal morphology (Yeates et al., 1993; Renčo, 2004; Hua et al., 2006; Liu et al., 2006; Meng et al., 2006; Liang et al., 2007).

Four ecological indices of nematode communities were calculated: (1) nematode taxon richness (S), S is the total number of genera (Ekschmitt et al., 2001); (2) Maturity in$\operatorname{dex}($ MI25), MI25 $=\Sigma v(i) \cdot f(i)$, where $v(i)$ is the $\mathrm{c}-\mathrm{p}$ value of taxon i (excluding c-p 1 group), f (i) is the frequency of taxon $\mathrm{i}$ in a sample (Bongers, 1990; Korthals et al., 1996; Nagy et al., 2004). (3) Structure index (SI), SI is a measure of the stable and structured status of a soil nematode community, was calculated according to the method of Ferris et al. (2001). (4) Nematode channel ratio (NCR), NCR = B/ $(\mathrm{B}+\mathrm{F})$, where $\mathrm{B}$ and $\mathrm{F}$ are the proportions of the nematode fauna allocated to bacterivorous and fungivorous groups (Yeates et al., 2003).

All the data were subjected to statistical analysis of variance (ANOVA) in the SPSS statistical package. Differences with $\mathrm{P}<0.05$ were considered significant.

\section{Results}

Significant differences in total and available $\mathrm{Cu}$ and available $\mathrm{Zn}$ concentrations were found between sampling sites $(\mathrm{P}<0.05)$, where $\mathrm{A}>\mathrm{B}>\mathrm{C}>\mathrm{D}$ (Fig. 1 and Fig. 2). These

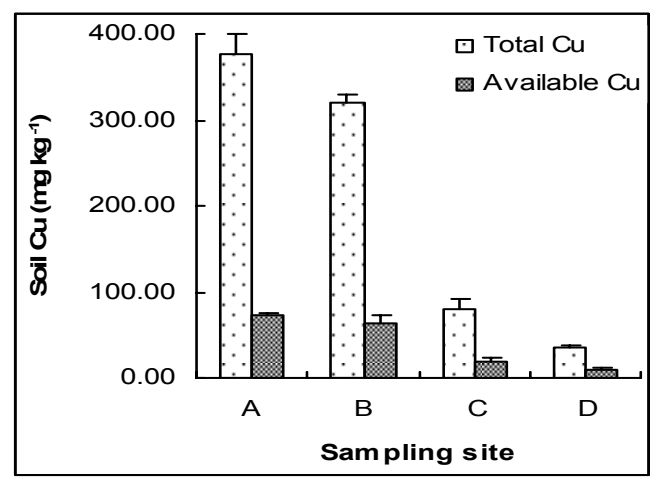

Fig. 1. Concentrations of total and available $\mathrm{Cu}($ mean $\pm \mathrm{SD})$ at different sampling sites along a pollution gradient (A, $50 \mathrm{~m}$; B, 150 m; C, 500 m; D, 1000 m from Hongtoushan copper smelter)

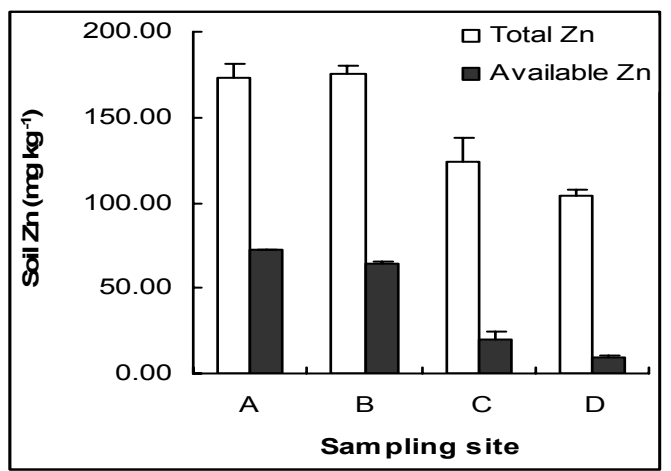

Fig. 2. Concentrations of total and available $\mathrm{Zn}($ mean $\pm \mathrm{SD})$ at different sampling sites along a pollution gradient

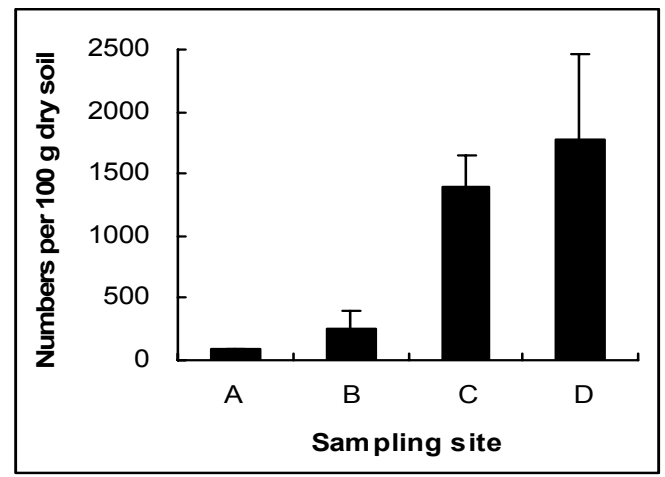

Fig. 3. Abundance of total nematodes (mean $\pm \mathrm{SD})$ at different sampling sites along a pollution gradient 
Table 1. Soil physicochemical properties at different sampling sites

\begin{tabular}{cccccrr}
\hline Site & $\begin{array}{c}\text { SM } \\
(\%)\end{array}$ & $\begin{array}{c}\text { Bulk Density } \\
\left(\mathrm{g} \mathrm{cm}^{-3}\right)\end{array}$ & $\mathrm{pH}$ & $\begin{array}{c}\mathrm{EC} \\
\left(\mu \mathrm{sm}^{-1}\right)\end{array}$ & $\begin{array}{c}\text { TOC } \\
\left(\mathrm{g} \mathrm{kg}^{-1}\right)\end{array}$ & $\begin{array}{c}\text { Total nitrogen } \\
\left(\mathrm{g} \mathrm{kg}^{-1}\right)\end{array}$ \\
\hline A & 12.1 & 1.42 & 5.25 & 158.9 & 14.6 & 1.3 \\
B & 15.9 & 1.37 & 5.35 & 120.0 & 11.4 & 1.2 \\
C & 16.5 & 1.36 & 5.41 & 126.9 & 12.4 & 1.3 \\
D & 18.2 & 1.10 & 5.19 & 167.9 & 14.2 & 1.0 \\
\hline
\end{tabular}

Explanations: SM - soil moisture; TOC - total organic carbon; EC - electrical conductivity

Table 2. The proportion (\%) of nematode genera and trophic groups at different sampling sites

\begin{tabular}{lccccc}
\hline \multicolumn{1}{c}{ Genus } & c-p & A & B & C & D \\
\hline BF & & $\mathbf{3 7 . 7}$ & $\mathbf{5 7 . 1}$ & $\mathbf{1 7 . 0}$ & $\mathbf{4 2 . 5}$ \\
Acrobeles & 2 & 0.0 & 0.0 & 0.0 & 2.0 \\
Acrobeloides & 2 & 21.8 & 28.8 & 8.6 & 13.3 \\
Eucephalobus & 2 & 8.5 & 6.8 & 0.0 & 6.8 \\
Plectus & 2 & 0.0 & 0.0 & 1.0 & 0.2 \\
Prismatolaimus & 3 & 3.0 & 10.1 & 3.7 & 1.5 \\
Protorhabditis & 1 & 4.4 & 9.5 & 0.7 & 15.6 \\
Wilsonema & 2 & 0.0 & 0.0 & 3.0 & 0.0 \\
FF & & $\mathbf{1 5 . 7}$ & $\mathbf{2 6 . 7}$ & $\mathbf{1 . 5}$ & $\mathbf{3 . 2}$ \\
Dorylaimoides & 5 & 3.1 & 4.9 & 0.0 & 0.0 \\
Tylencholaimus & 4 & 0.0 & 0.0 & 0.0 & 0.2 \\
Paraphelenchus & 2 & 12.6 & 21.8 & 1.5 & 3.2 \\
PP & & $\mathbf{4 6 . 6}$ & $\mathbf{1 8 . 3}$ & $\mathbf{7 2 . 6}$ & $\mathbf{5 4 . 3}$ \\
Bitylenchus & 3 & 2.1 & 0.0 & 16.7 & 3.0 \\
Coslenchus & 2 & 0.0 & 0.0 & 3.2 & 0.0 \\
Filenchus & 2 & 7.5 & 0.2 & 16.7 & 3.0 \\
Macroposthonia & 3 & 9.1 & 1.0 & 0.0 & 0.5 \\
Paratylenchus & 2 & 14.0 & 17.1 & 13.2 & 39.9 \\
Pratylenchus & 2 & 13.9 & 0.0 & 28.9 & 7.9 \\
OP & & $\mathbf{0 . 0}$ & $\mathbf{0 . 0}$ & $\mathbf{8 . 2}$ & $\mathbf{2 . 9}$ \\
Aporcelaimellus & 5 & 0.0 & 0.0 & 8.2 & 1.7 \\
Discolaimus & 5 & 0.0 & 0.0 & 0.0 & 0.3 \\
Epidorylaimus & 4 & 0.0 & 0.0 & 0.7 & 0.0 \\
Thonus & 4 & 0.0 & 0.0 & 0.0 & 0.9 \\
\hline & & & & & \\
\hline & & & & \\
& & & &
\end{tabular}

Explanations: $\mathrm{BF}$ - bacterivores; $\mathrm{FF}$ - fungivores; $\mathrm{PP}$ - plant parasites; $\mathrm{OP}-$ omnivores-predators. $\mathrm{c}-\mathrm{p}$ values for nematode genera were based on Bongers (1990) results indicated that total and available $\mathrm{Cu}$ and available $\mathrm{Zn}$ concentrations decreased with increasing distance from the smelter. According to the China environmental quality standard for soils (GB 15618 - 1995), total $\mathrm{Cu}$ contents at site A and B belong to quality class III, while those at site $\mathrm{C}$ and $\mathrm{D}$ belong to quality class II; total $\mathrm{Zn}$ contents at all the sites belong to quality class II. These results indicated that soil at site A and B were unsuitable for agricultural use, and site $\mathrm{C}$ and $\mathrm{D}$ were suitable for agricultural use.

Twenty genera of nematodes were identified in our investigation (Table 2), and Paratylenchus was dominant genus at all the sampling sites. The number of Paratylenchus negatively correlated with total and available $\mathrm{Cu}(\mathrm{P}<0.05)$ and $\mathrm{Zn}(\mathrm{P}<0.01)$. Acrobeloides and Paraphelenchus were found to be dominant genera at A and B, while Bitylenchus and Pratylenchus were dominant at site $\mathrm{C}$.

Significant differences in the number of total nematodes were found between sampling sites $(\mathrm{P}<0.01)$, where $\mathrm{A}<$ $\mathrm{B}<\mathrm{C}<\mathrm{D}$ (Fig. 3). The number of total nematodes negatevely correlated with total $\mathrm{Cu}(\mathrm{P}<0.01)$, total and available Zn $(\mathrm{P}<0.01)$ (Table 3).

Significant differences in the numbers of bacterivores, plant parasites and omnivores-predators were found between sampling sites $(\mathrm{P}<0.05)$. The number of plant parasites exhibited a similar trend to those of total nematodes. Omnivores-predators were the least abundant trophic group, averaging from $0.0 \%$ to $8.2 \%$ of the nematode community (Table 2). The numbers of bacterivores, plant parasites and omnivores-predators negatively correlated with total $\mathrm{Cu}(\mathrm{P}<0.05)$, total and available $\mathrm{Zn}(\mathrm{P}<0.05)$ (Table 3).

Table 3. Correlation coefficients for soil nematodes and soil chemical properties at different sampling sites

\begin{tabular}{clrllll}
\hline Indicator & \multicolumn{1}{c}{$\mathrm{pH}$} & $\mathrm{EC}$ & Available $\mathrm{Cu}$ & Available Zn & \multicolumn{1}{c}{ Total Cu } & Total Zn \\
\hline TNEM & 0.001 & 0.414 & -0.281 & $-0.868^{* *}$ & $-0.878^{* *}$ & $-0.885^{* *}$ \\
BF & 0.132 & 0.120 & -0.499 & $-0.687^{* *}$ & $-0.725^{* *}$ & $-0.770^{* *}$ \\
FF & 0.324 & -0.358 & -0.381 & -0.026 & -0.131 & -0.100 \\
PP & -0.015 & 0.165 & 0.015 & $-0.863^{* *}$ & $-0.886^{* *}$ & $-0.888^{* *}$ \\
OP & 0.367 & 0.038 & 0.188 & $-0.574^{*}$ & $-0.669^{*}$ & $-0.649^{*}$ \\
S & 0.263 & 0.427 & 0.285 & -0.398 & -0.404 & -0.492 \\
MI2-5 & 0.387 & -0.036 & 0.291 & -0.451 & -0.534 & -0.501 \\
SI & 0.460 & -0.095 & 0.163 & -0.504 & $-0.585^{*}$ & -0.546 \\
NCR & -0.075 & 0.203 & -0.101 & $-0.752^{* *}$ & $-0.737^{* *}$ & $-0.745^{* *}$ \\
\hline
\end{tabular}

Explanations: *,**-Correlations are significant at $\mathrm{P}<0.05$ and 0.01 levels, respectively 
Significant differences in the selected ecological indices were found between sampling sites $(\mathrm{P}<0.05)$. The highest value of $S$ (number of genera) was 16 at site $\mathrm{D}$, and the lowest 9 at site B. The lowest values of MI2-5 and SI were found at site A. The values of NCR showed the same trend with those of $\mathrm{S}$ (Table 4). The values of SI negatively correlated with total $\mathrm{Cu}(\mathrm{P}<0.05)$, and those of NCR negatively correlated with total $\mathrm{Cu}(\mathrm{P}<0.01)$, total and available $\mathrm{Zn}(\mathrm{P}<0.01)$ (Table 3).

Table 4. Nematode ecological indices at different sampling sites

\begin{tabular}{lcccc}
\hline Site & S & MI2-5 & SI & NCR \\
\hline A & 11 & 2.23 & 33.30 & 0.73 \\
B & 9 & 2.26 & 37.92 & 0.65 \\
C & 13 & 3.10 & 78.57 & 0.92 \\
D & 16 & 2.32 & 43.65 & 0.93 \\
P-values & 0.037 & 0.023 & 0.037 & 0.017 \\
\hline
\end{tabular}

Explanations: $\mathrm{S}$ - nematode taxon richness; MI2-5 - maturity index (25); SI - structure index; NCR - nematode channel ratio

\section{Discussion}

Aerial deposition of $\mathrm{Cu}$ and $\mathrm{Zn}$ emitted from the adjacent smelter caused an increase in heavy metal concentrations in the investigated soils. The highest concentrations were found at site A (site closest to the smelter) and the lowest at site $\mathrm{D}$ (the most remote site) in our study. These results were partly in agreement with those of Tobor-Kapłon et al. (2006), reported from the vicinity of a zinc smelter in Budel, the Netherlands. The number of total nematodes exhibited a gradual increasing trend with increasing distance from the copper smelter in our investigation. This result was in agreement with that of Shukurov et al. (2005), who observed it in the vicinity of an industrial complex in Uzbekistan. However, it was inconsistent with the finding of $\mathrm{Li}$ et al. (2006) that the $\mathrm{Cu}$ and $\mathrm{Zn}$ had positive effects on soil nematodes near a metallurgical factory in the lower reaches of Liao River Plain, Northeast China. The discrepancy may be a consequence of the lower concentrations of $\mathrm{Cu}$ and $\mathrm{Zn}$ in our previous study (Li et al. 2006), since the lower concentrations of $\mathrm{Cu}$ and $\mathrm{Zn}$ in soil could stimulate the hatching of nematode eggs (Clarke \& Shepherd, 1966). Significant correlations with the total contents of $\mathrm{Cu}$ and $\mathrm{Zn}$ were found in this study, but not or weak correlations with available contents of $\mathrm{Cu}$ and $\mathrm{Zn}$. The reason for the latter was that soil temperature was very low during this sampling time and would decrease the contents of available $\mathrm{Cu}$ and $\mathrm{Zn}$.

The numbers of bacterivores, plant parasites and omnivores-predators correlated negatively with total $\mathrm{Cu}$, total and available $\mathrm{Zn}$ in soil in our study. These results indicated that $\mathrm{Cu}$ and $\mathrm{Zn}$ had negative effects on most trophic groups. Omnivores-predators were in our study the least abundant and the most sensitive trophic group to heavy metal pollution; no genus was found at site $\mathrm{A}$ and $\mathrm{B}$.
Similar results were found by Georgieva et al. (2002), who re-ported that omnivores-predators were reduced or eliminated from the nematode communities in soil with high $\mathrm{Cu}$ and $\mathrm{Zn}$ concentrations. However, positive effects due to a moderate level of $\mathrm{Cu}$ and $\mathrm{Zn}$ application on nematode abundance and taxon richness were reported by Nagy (1999); and in the Zn treated plots even MI and the proportion of omnivores-predators increased compared with the control (Nagy, 1999). Moreover, some stimulative effects of $\mathrm{Cu}$ on many genera at low concentrations were found in a laboratory experiment added to different $\mathrm{CuSO}_{4}$ solutions in The Netherlands (Bongers et al., 2001). There is evidence for comparable effects of $\mathrm{Cu}$ and $\mathrm{Zn}$ to the findings of present study.

Nematode richness (S), as indicated by the number of genera, proved to be a very suitable tool showing a consistent correlation with mass and microflora in the grassland soils (Ekschmitt et al., 2001). The values of $\mathrm{S}$ in our study ranged from 9 to 16, which were consistent with those observed by Li et al. (2006) in the vicinity of a metallurgical factory in the lower reaches of Liao River Plain. MI measured disturbances with a lower value indicating a more disturbed environment (Bongers, 1990). MI2-5 value (excluding c-p 1 group) gave a much better response to disturbances than the MI (Nagy et al., 2004). The values of MI25 in our investigation ranged from 2.23 to 3.10, which showed a similar trend with those reported by Nagy et al. (2004) in an agricultural field in Hungary. Nematode channel ratio (NCR) reflects the soil decomposition pathway. The values of NCR ranged from 0.67 to 0.93 with higher values found at site $C$ and $D$ compared with site $A$. The values of NCR indicated the bacterial decomposition pathway was relatively more dominant at site $\mathrm{C}$ and $\mathrm{D}$. The values of NCR correlated negatively with total $\mathrm{Cu}$, total and available $\mathrm{Zn}$ in our study. These results were in agreement with those found by Yeates et al. (2003) in New Zealand.

In conclusion, soil heavy metals $(\mathrm{Cu}$ and $\mathrm{Zn})$ near a copper smelter had adverse effects on the numbers of total nematodes, bacterivores, plant parasites and omnivores-predators. Among the nematode ecological indices examined, SI and NCR were found to be sensitive indicators for assessing the effect of heavy metals on soil nematode communities in this study.

\section{Acknowledgements}

This research was supported by the National Natural Science Foundation of China (No. 30600087). The authors wish to express their appreciation to Dr. P. Nagy (Szent István University, Hungary) for his constructive review of this manuscript.

\section{References}

BONGERS, T. (1990): The maturity index: an ecological measure of environmental disturbance based on nematode species composition. Oecologia, 83: $14-19$ 
Bongers, T., FERris, F. (1999): Nematode community structure as a bioindicator in environmental monitoring. Trends Ecol. Evol., 14: 224 - 228

BOngers, T., Ilieva-MaKulec, K., EKschmitT, K. (2001): Acute sensitivity of nematode taxa to $\mathrm{CuSO}_{4}$ and relationships with feeding type and life-history classifycation. Environ. Toxicol. Chem., 20: 1511 - 1516

Clarke, A. J., ShePherd, A. M. (1966): Inorganic ions and the hatching of Heterodera spp. Ann. Appl. Biol., 58: $497-508$

Cortet J. Gomot-De Vauflery, A., Poinsot-BalaGuer, N., Gomot, L., Texier, C., Cluzeau, D. (1999): The use of invertebrate soil fauna in monitoring pollutant effects. Eur. J. Soil Biol., 35: 115 - 134

EKschmitt, K., BAKONYI, G., Bongers, M., Bongers, T., BosröM, S., Dogan, H., HARrison, A., NAGY, P., O’Donnell, A. G., Papatheodorou, E. M., Sohlenius, B., Stamou, G. P., Wolters, V. (2001): Nematode community structure as indicator of soil functioning in European grassland soils. Eur. J. Soil Biol., 37: $263-268$

Ferris, H., Bongers, T., DeGoede, R. G. M. (2001): A framework for soil food web diagnostics: extension of the nematode faunal analysis concept. Appl. Soil Ecol., 18: 13 $-29$

Georgieva, S. S., McGrath, S. P., Hooper, D. J., Chambers, B. S. (2002): Nematode communities under stress: the long-term effects of heavy metals in soil treated with sewage sludge. Appl. Soil Ecol., 20: 27 - 42

HUA, J. F., JiAnG, Y., LiANG, W. J. (2006): Response of nematodes in a Hapli-Udic Argosol to urea amended with urease and nitrification inhibitors. Pedosphere, 16: $428-$ 434

Korthlas, G. W., De Goede, R. G. M., Kammenga, J. E., Bongers, T. (1996): The maturity index as an instrument for risk assessment of soil pollution. In VAN STRAALEN, N.M., KRVOLUTSKY, D.A. (Eds.): Bioindicator Systems for Soil Pollution. Kluwer Academic publishers, The Netherlands, pp. 85 - 93

LI, Q., JIANG, Y., LIANG, W. J. (2006): Effect of heavy metals on soil nematode communities in the vicinity of a metallurgical factory. J. Environ. Sci., 18: 323 - 328
LiAnG, W. J., LI, F. P., Li, Q., ZHANG, W. D. (2007): Temporal dynamics of soil nematode community structure under invasive Ambrosia trifida and native Chenopodium serotinum. Helminthologia, 44: 29 - 33

LIANG, W. J., LI, Q., ZHANG, X. K., JiANG, S. W., JiANG, Y. (2006): Effect of heavy metals on soil nematode community structure in Shenyang suburbs. Am.-Eur. J. Agric. Environ. Sci., 1: $14-18$

LIU, Y., HuA, J., JiANG, Y., LI, Q., WEN, D. (2006): Nematode communities in greenhouse soil of different ages from Shenyang suburb. Helminthologia, 43: $51-55$

Meng, F. X., OU, W., LI, Q., JiANG, Y., WEN, D. (2006): Vertical distribution and seasonal fluctuation of nematode trophic groups as affected by land use. Pedosphere, 16: $169-176$

NAGY, P. (1999): Effects of an artificial metal pollution on nematode assemblage of a calcareous loamy chernozem soil. Plant Soil, 212: 35 - 43

NAgy, P., BAKonyi, G., Bongers, T., KÁdÁr, I., FÁBiÁN, M., KISS, I. (2004): Effects of microelements on soil nematode assemblages seven years after contaminating an agricultural field. Sci. Total Environ., 320: 131 - 143

NEHER, D. A. (2001): Role of nematodes in soil health and their use as indicators. J. Nematol., 33: $161-168$

RENČO, M. (2004): Communities of nematodes in cereal fields following sugar beet. Helminthologia, 41: $109-122$

Shukurov, N., Pen-Mouratov, S., Steinberger, Y. (2005): The impact of Almalyk Industrial Complex on soil chemical and biological properties. Envrion. Pollut., 136: $331-340$

Tobor-KapŁon, M. A., Bloem, J., Römkens, P. F. A. M., DE RUITER, P. C. (2006): Functional stability of microbial communities in contaminated soils near a zinc smelter (Budel, The Netherlands). Ecotoxicology, 15: 187 - 197

Yeates, G. W., Bongers, T., De Goede, R. G. M., FreckMan, D. W., Georgieva, S. S. (1993): Feeding habits in soil nematode families and genera - an outline for soil ecologists. J. Nematol., 25: $315-331$

Yeates, G. W., Percival, H. J., Parshotam, A. (2003): Soil nematode responses to year-to-year variation of low levels of heavy metals. Aust. J. Soil Res., 41: $613-625$ 